\title{
Marcellin Richard, La Passion de Saint André
}

\section{Michele Mastroianni}

\section{(2) OpenEdition}

\section{Journals}

\section{Edizione digitale}

URL: http://journals.openedition.org/studifrancesi/9450

DOI: $10.4000 /$ studifrancesi. 9450

ISSN: 2421-5856

\section{Editore}

Rosenberg \& Sellier

\section{Edizione cartacea}

Data di pubblicazione: 1 décembre 2007

Paginazione: 636

ISSN: 0039-2944

\section{Notizia bibliografica digitale}

Michele Mastroianni, «Marcellin Richard, La Passion de Saint André», Studi Francesi [Online], 153 (LI]

III) | 2007, online dal 30 novembre 2015, consultato il 08 janvier 2021. URL: http://

journals.openedition.org/studifrancesi/9450 ; DOI: https://doi.org/10.4000/studifrancesi.9450

\section{Questo documento è stato generato automaticamente il 8 janvier 2021.}

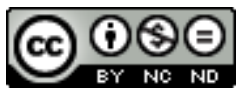

Studi Francesi è distribuita con Licenza Creative Commons Attribuzione - Non commerciale - Non opere derivate 4.0 Internazionale. 


\title{
Marcellin Richard, La Passion de Saint André
}

\author{
Michele Mastroianni
}

\section{NOTIZIA}

MARCELLIN RICHARD, La Passion de Saint André, édition critique suivie d'une étude linguistique comparée par Jean SIBILLE, Paris, Champion, 2007 («Textes de la Renaissance», 110), pp. 953.

1 La regione di Briançon, che comprendeva fra Tre e Cinquecento, sui due versanti delle Alpi, cinque circoscrizioni che si estendevano fino alla Val di Susa (Oulx e Chiomonte), era una regione di confine anche linguistico in cui si incontravano francoprovenzale e dialetto piemontese. In tale zona, fra Quattro e Cinquecento, fiorì una ricca produzione drammatica (di Misteri e Passioni) che offre testimonianze preziose per lo studio della lingua occitanica. Di una di questi testi, La Passion de Saint André, rappresentata nel 1512, vi è ora offerta l'edizione critica con traduzione a fronte in francese moderno. L'Introduzione disegna un quadro storico della produzione drammatica della regione di Briançon, che colpisce per l'abbondanza e la coerenza. Ma l'interesse del volume è costituito dai due vasti studi linguistici che accompagnano l'edizione. Il primo ( $L a$ langue des mystères alpins. Études comparatives, pp. 309-460) situa la lingua dei Misteri alpini nel quadro dei dialetti occitani e nella famiglia gallo-romanza. Il secondo ( $L a$ langue de la Passion de Saint André. Grammaire comparée, pp. 463-855) offre una grammatica del testo (grafia e fonetica, morfologia e morfosintassi, lessico) in una prospettiva di raffronto comparato con gli altri Misteri alpini, e fornisce allo studioso un modello di ricostruzione di una lingua di frontiera, cerniera fra vari parlati. 